\title{
Support to insurgency and counter insurgency operations $^{1}$
}

\author{
Vlasta ZEKULIĆ ${ }^{2}$, Ana ŽUŽIĆ ${ }^{3}$, Adam PIŠKULIĆ ${ }^{4}$
}

\section{Introduction}

Since the end of the $20^{\text {th }}$ Century the role and ultimate power of states have been diminishing. Once, states were considered untouchable no matter what happened within their borders and no matter who ruled them, but nowadays, international intervention into intra-state affairs has become quite common. Ungoverned, undergoverned, misgoverned and contested areas offer fertile ground for insurgents, extremists, organized crime and warlords to flourish and consequently endanger not only local civilian populations but also the political, security, economic or ideological interests of western powers. Consequently, two separate approaches to intra-state interventions have been developed: backing the government in their fight against the insurgency, such as in Afghanistan, and backing the insurgents in their fight against the government such as in Libya.

First, this article will analyze the changed role of the states in the New World Order and define parameters that guide international interventions into the intra-state affairs. Secondly, it will analyze western approaches to insurgency and counter insurgency operations through a case study of NATO operations in Afghanistan and Libya.

\section{Role and status of states in the new world order}

Until two decades ago, intervention in intra-state questions and crisis would have been unimaginable. This was established by the 1648 Treaty of Westphalia, which upheld the right of sovereign states to act freely within their own borders. Additionally, it was backed up by 1945 Charter of the United Nations article 2/7: "Nothing contained in the present Charter shall authorize the United Nations to intervene in matters which are essentially within the domestic jurisdiction of any state or shall require the Members to submit such matters to settlement under the present Charter. "[1] Despite this, and in the light of the bloody and brutal conflicts of the 1990s, tension rose between principles of sovereignty and intervention. This article will answer what has changed that gives evermore authority to the international community to intervene and support one of the opposing sides in intra-state conflicts.

The end of the Cold War and the bipolar division of the world ended the support of the powerful allies to the weaker African and Asian states, many of these plummeted into civil wars for power, justice, human rights or for resources, both deficient and abundant ones.

1 This article is the written form of the presentation that was shown on the Central European Forum on Higher Military Education (CEFME) International Young Scientists Conference on December 2013, NUPS, Budapest

2 major, PhD, vzekulic@morh.hr

3 cadet

4 cadet 
Nathan Lauri states that intra-state crises most often rose from four structural reasons: authoritarian rule, the marginalization of minorities, relative socio-economic deprivation or weak states. [2]

The changes that led to these circumstances did not occur overnight. They resulted from the versatile political and apolitical factors that happened not only in the states themselves, but also in their surroundings. Most analyses indicate that instability springs from the weak dynamics of the political processes in which expectations from state and citizens are not in balance. When states cannot fulfill their societies' demands, it leads to peoples' dissatisfaction and lowering of the states' legitimacy. The fact that the state has been dragged into crisis, war or a conflict means that the crucial institutions of pre-conflict power failed in the state management, monopoly of the use of force, sustained stable social relations, protection of its citizens and, in most cases, in the protection of a functional market. In order to maintain a stable state capable of dealing with constant changes, governments need to conduct constant adjustments and alignments in: [3: 6-10]

1. Political settlements. They are used to emphasize centralization of state management and persuade political, industrial and military elites of the benefits of coexisting. Hobbes critically observed that "unity among people is not natural; it comes out of a contract that is artificial."[4: 122] Political settlements fulfill needs and interests of individuals and groups, but the ability to form and focus them towards the greater good is of crucial importance for sustainability and stability of the states.

2. Survival functions. States must develop capacity in relation to: security (ability to control, if not monopolize, the use of violence); revenue (the ability to raise funds sustainably, particularly through taxation) and law (the capability to rule through laws).

3. Expected functions. They are used to prove and verify legitimacy of state structures. They represent the minimum capacity needed for the state to exert its power over people by satisfying their basic needs.

Being involved in conflict or war additionally impedes the functioning of the states and in many cases gives room for development of new organizational forms on a sub-state level, new economies and new relations, loyalties and spheres of interests. According to Claire McIoughlin the relationship between conflict and fragility is circular: conflict is both cause and consequence of weak authority and state legitimacy. [5]

In attempts to deal with crisis, most states lose institutional capacity to fulfill their duties within executive, parliamentary or judiciary spheres. They become fragile and unresponsive. Fragility is not something that can be clearly defined; it varies in its content, intensity and capacity. Fragility has many causes - chronic and acute ones, and it leads to many consequences such as poverty, vulnerability to inter and intra state conflicts, inability to deal with humanitarian disasters and a high risk of states' political collapse. Governments that lack resources and expertise to resolve disputes and grievances and to protect their legitimacy to manage competition and protect the rights of citizens, enable individuals and groups to disrupt their governance even more and seize power by all means available and deemed necessary. [2]

Bloody and ruthless clashes stemming from the aforementioned fragility raise multiple concerns: those for human security, state and regional stability and development and economic growth as well as a strong belief that instability and underdevelopment are mutually interlinked and supported. Nathan stated that "Large-scale domestic violence prevents the 
attainment of security communities because it renders people and states insecure, generates uncertainty, tension and mistrust among states, and creates the risk of cross-border violence." [6] In other words, weak and fragile states can no longer "keep” their insecurity within their borders, uncontrolled terrain becomes the training ground for terrorists, extremists and criminal groups as weapons, drugs, people and other contraband flow through the regions unchecked and enters rich countries of the West. This raises alarm within the international community and it rises to arms and gets involved in the fight.

\section{Insurgency vs Counterinsurgency}

As stated in the previous chapter, main threats, insecurities and instabilities for the western powers come from weak, fragile and dysfunctional states. They are most often involved in some type of inner struggle, crisis or conflict. Before we can explain foreign involvement in the support of insurgents or the governments fighting against them, this article will define main principles of insurgency and counterinsurgency.

\section{Insurgency}

NATO defines insurgency as "the actions of an organized, often ideologically motivated, group or movement that seeks to effect or prevent political change of a governing authority within a region, focused on persuading or coercing the population through the use of violence and subversion." [8: 1-2] Insurgents attempt to achieve their goals through the use of various political and military means, applying tactics such as violence, subversion and propaganda.

Insurgencies normally seek to achieve one of three objectives:

1. to overthrow the existing government in order to reallocate power,

2. to expel whom they perceive to be "outsiders" or "occupiers" or,

3. to seek to create or maintain a region where there is little or no governmental control that they can exploit. [8: 2-7]

Need, will, and motivation to rebel come out of core grievances stated previously in the text: feelings of suppressed socio-cultural identity that is conflicting (such as the black majority against apartheid in South Africa in 1980s); religion (as was the cause of 30-years of rebellion of Christian blacks in the south Sudan against the ruling Arab Muslims of the north Sudan ending in 2010); economy; corruption and lack of essential services (such as in Egypt during the Arab spring movements of 2010); repression (such was in Libya under Gaddafi's rule); foreign exploitation and occupation (as was the case in Vietnam during 1960-70s) etc.

Both NATO and US counterinsurgency doctrines recognize that for both insurgents and governments they fight, population vulnerability is a key prize. Under the right leadership and ideological cloak, the population may bring prevailing victory to one side or the other. Thus, one of the main steps for insurgents is to convince and prove to the population that the ruling government is incapable of providing and securing them. In order to do this, insurgent organizations must create good "management" structure that is most often made up of five elements: leaders, guerrillas, underground, auxiliaries and mass base. [8: 3-12, 13]

Leaders provide vision, direction, guidance, coordination and organization for an insurgent movement. They have force of personality, the power of revolutionary ideas and personal charisma. There are generally three categories of leadership: single person, single group 
or party and group of groups. One person leadership structure has one person who provides cohesion, motivation and direction for the insurgency. Such was Osama Bin Laden for AlQaida. The insurgency may be headed by a ruling council that makes and executes policy. The lead group contains many leaders with different concepts of how the movement should be conducted or lead.

A guerrilla does the actual fighting for the insurgency. The RAND study on trends in outside support for insurgency concludes that "In ideological, religious and nationalist insurgencies, militants risk their lives, and possibly those of their friends and families, to further the set of beliefs. Thus self-reliance, dedication to the struggle and self-denial are extremely useful qualities in rebel groups." [9: 83] They are usually the faceless masses that execute the leader's visions and ideas.

The support can be external, internal or an underground one. It gathers active supporters who usually must operate secretly, especially during the preparation of the insurgency. The underground may spread propaganda, support sabotage, assassination and subversion, support intelligence and counterintelligence operations, run safe houses, provide transportation and manufacture and maintain arms and explosives. [8: 2-4] In its' study of outside support for insurgent movements RAND diversified three main forms of support to rebels: critical ones (such as providing safe haven, transit, finances, political support and propaganda, and sometimes even direct military support); valuable ones (such as training, weapons and materiel); and minor forms of support (such as fighters, intelligence, organizational aid and inspiration). [9: 84-102]

An auxiliary is the support element of the insurgency (usually they are children and women). They provide important logistical services safer than the underground does, and they do not directly participate in operations. Examples of support that auxiliaries provide include: storing weapons and supplies, performing courier operations, providing passive intelligence collection, giving early warnings of counterinsurgent movements, acquiring funds from lawful and unlawful sources, providing forged or stolen documents, promoting and facilitating desertion of security forces, recruiting and screening new members, creating and spreading propaganda, providing medical support and manufacturing and maintaining equipment. [8: 3-16]

The mass base consists of the population of the true silent supporters of the insurgent movement. Leaders often recruit members of the mass base, who are actively oriented, to serve as auxiliaries, underground or guerrillas.

NATO COIN doctrine identified main insurgents' vulnerabilities that become exposed during their fight. [7] First among these is security. As the insurgency expands, it becomes harder to keep their activities, locations and key personnel a secret, which exposes their "flanks" to government COIN ops. There is an inherent tension between the need to grow popular support and the need to maintain organizational security. It directly influences where they wish to establish their bases of operations - further away from center would be safer but harder to act; however, placing them close by would increase the risk of getting discovered.

If insurgents decide to decentralize their organization to increase safety, they face another set of challenges: the flow of information, resources, encouragement or directions become much harder. Having longer and more exposed lines of supply make them more vulnerable and fragile. But decreasing support could make their members feel secluded and isolated, which could lead to development of their own narrative, path or direction that can indicate a split in the insurgents' unity of effort, leading to factionalism within the leadership. 
NATO experts conclude that "nothing is more demoralizing for insurgents than to realize that people inside their movement or trusted supporters are deserting the insurgency or providing information to government authorities" [8: 3-17] and this is the moment when counterinsurgency starts its major operations.

\section{Counterinsurgency}

Counterinsurgency (COIN) encompasses all "those military, paramilitary, economic, psychological and civil actions which government takes for defeating an insurgency." [8: 3-1] It can be conducted by the very government facing insurgency alone or in union with the international community and foreign assistance. Because it needs to disrupt the operational tempo of the insurgents, the government needs to develop a strategic-political, operational and tactical dimension. Since political considerations are of much greater importance than military considerations in a struggle for the consent of the population, every COIN action should support a political resolution to the problem.

While insurgents aim to expose government's inadequacies and falsehoods, ruling governments need to recognize and understand the full range of insurgent actors, their motivations, aspirations, interests and relationships. As stated before, both sides fight for the inclination of the population. Insurgents most often hide among the civilians: they do not carry visible insignia or uniforms, and can often be taken for the innocent and impartial bystanders, so NATO COIN doctrine stresses "it is a struggle for the population, not against the population” even when the population turns against ruling elites. [8: 3-20] If this principle is not obeyed, the situation may lead to the one similar to Afghanistan where "Afghan people hate the Taliban, but they equally despise the government." [10: 11]

Additionally, NATO defines some other attributes of COIN, such as: political primacy (need to have a clearly-defined political objective) and relevancy of the full legitimacy of government as well as the need to provide security under the rule of law. It also warns that insurgencies are often long lasting. Some reports state that the average duration of successful insurgencies was 14 and unsuccessful ones 11 years, and this could not be possible without the ability to learn and adapt to new techniques, tactics and procedures. In order to do this, all operations need to be intelligence driven with a clear unity of effort, goals, visions and strategies. In the military spectrum of operations the first and crucial goal is to neutralize the insurgency by isolating them from their support. As their backing system breaks, so will the ability to wage operations.

Another important military factor in COIN is the terrain. [10: 2] The nature and size of urban population increasingly hamper a counterinsurgent's ability to detect and identify insurgents. In urban centers insurgents easily hide in masses and have increased freedom of movement in observing and approaching their targets. This is the reason why the two most deadly and violent attacks in Afghanistan during 2012-2013 were in fact in Kabul, its capital city, despite the extensive net of police, military and intelligence agencies available. In fact, the attacks were at the intelligence base and main city traffic police headquarters, the very institutions meant to protect the people. ${ }^{5} \mathrm{COIN}$ forces may have to emphasize intelligence and police operations to counter covert organizational, intelligence, logistic and terrorist ac-

5 From personal experience of Maj. Zekulić, serving in Afghanistan, Kabul as the member of NATO forces at the time of attacks. 
tivities, and carefully plan and coordinate all operations, particularly those involving use of deadly force, as there is a high risk of collateral damages.

Militaries sometimes call COIN a "clear-hold-built" operation. In its full spectrum they combine offense operations ("Clear" meaning finding and eliminating the insurgent), defense ("Hold" meaning establishing the presence and protecting the local populace) and stability operations ( "Build" meaning rebuilding the infrastructure, increasing the legitimacy of the local government and bringing the rule of law to the area). [8: 3-17]

When foreign states step in the intra-state crisis they consequently became legitimate targets as well. According to the Law of armed conflict, theatre of war is any space where military operations are prepared and executed, making the confrontation much more comparable to full spectrum war, then civil conflict. We saw examples of this when Islamist extremist conducted attacks on Madrid, London and attempted to do them in Germany and Denmark, as a response to their engagement in Afghanistan. On the other side, the US justified their raids in Pakistan by claiming that the Pakistan government was shielding and protecting the Taliban insurgents and Al-Qaida operatives.

\section{International responses to insurgency and counterinsurgency}

Whether the western powers get involved in intra-state conflicts to support insurgents, or to support governments in their struggle against insurgency, depends on multiple factors. Countries that are ruled in opposition to democratic principles, who brutally suppress human and minority rights or who prevent fair access to natural and mineral resources, could be a potential target for international intervention. According to Nathan, following causes may trigger international intervention into intra state matters ${ }^{6}$ : [11]

- Proximity, the risk of cross border violence and instability is greatest among adjacent countries. In case of Africa and Europe, the Mediterranean Sea is considered not as a buffer zone of separation, but as the mitigating and hard to control medium through which insecurity factors and actors may easily enter. This was one of the reasons for French led EU intervention in Mali in 2013.

- Military balance of power, as the likelihood of military intervention would be smaller if the opposing party had significant military might that could significantly jeopardize lives of NATO/EU troops. Such was the case of operation "Allied Force” against Serbia in 1999, when the decision was made to conduct operations only through air strikes, estimating that putting troops on the ground would be too risky.

- Regional organization and norms that guide foreign policies towards protection of their national or international interests. In support of this aspect, we can observe extensive EU interest in security situations in Africa and the Near East, whilst NATO is more oriented towards controlling security and stability in Asian and Caucasus region. Depending on whether the preferred security status is provided by the governments in power (such as in Afghanistan) or by the insurgents (such as in Syria) foreign intervention may occur in support of one party or the other.

- Structural instability is the precondition for the worsening of the favorable industrial and economic culture in the region of interest. Intervention by EU and NATO into

6 Other factors include: strategic culture, defensive versus offensive motivations. [11] 
Somalia and the Gulf of Aden to fight Somali pirates was predominantly guided by the need to protect merchant and cargo ships, thus enabling continuation of trade and business.

US National Defense Strategy, published in June 2008 clearly states that "violent extremist ideology adherents reject state sovereignty, ignore borders, and attempt to deny self-determination and human dignity wherever they gain power... Combating these violent groups will require long-term, innovative approaches." [12: 2]

That is why the attention of the international community returned to Somalia after it was left to plummet into civil war in 1993. Although it has not had a stable central government since 1991, the situation in 2005 became so dire due to an increase of piracy and increase of terrorist attacks planned and prepared in an Al-Qaida base stationed on the Somali island of Eas Komoboni, that something had to be done. US, NATO and EU troops sailed the seas, while AU sent 1,700 Sudanese and Ugandan troops to protect the regime's limited presence at Baidoa and Johwar and assisted them in fighting the Islamic extremists' and warlords' rebellions. [13: 24]

On the other hand there are many instances when states provide direct military support to the insurgents, sometimes even using their own armies to fight alongside them. Without them, they would remain marginalized and struggle merely to survive. Such was the case in Congo during the first and second Congo War, or the "Great African war". Before Laurent Kabila obtained the support of Rwanda and Uganda, he was a murky guerrilla leader who posed little danger to the regime. With their political and military support, he eventually overthrew it and became the president. As his “friendship” with Rwanda and Uganda cooled, they attempted to overthrow him, and would probably have succeeded if it were not for assistance from seven other states: Zimbabwe, Angola, Chad, Sudan and Namibia. [14]

We discussed earlier general concepts behind the term insurgency and counterinsurgency, but different nations and organizations use different terms to explain and justify their engagement in intra-state conflicts. For example, the US military doctrines use the term Foreign Internal Defense (FID) and Internal Defense and Development (IDAD). Both concepts encompass actions by "civilian and military agencies of one government in programs taken by another government to free and protect its society from subversion, lawlessness and insurgency." [15] FID can also be defined as an effort that involves numerous US Government agencies where they are all working together to eliminate the root causes of an insurgency in certain areas. The US Special Forces' doctrine also states that "FID also supports stability operations designed to promote and protect US national interests by influencing adversarial, political, and information operational variables in a region or country..." [16]

Nevertheless, international intervention will most likely occur where there is a case of grave violation of human rights or threat of massive violence overflow in the region. In such circumstances, western powers might initiate humanitarian intervention operations.

\section{Humanitarian intervention}

UN Charter and Law of War emphasize the principle of nonintervention and forbid aggression, in case of crises and conflicts that can occur within a State. But the 1990s brought the so-called, "CNN effect” that forced people to face humanitarian catastrophes and killing of civilians from the comforts of their own homes. These images activated the collective con- 
science of the population that pressed their political leaders to react. On the eve of the NATO campaign in Kosovo in 1999, Tony Blair became one of the first world leaders to assert a moral right to "get actively involved in other people's conflicts" even without the mandating resolution of the UN Security Council. He stated the need to wage a "just war, based not on territorial ambitions, but on values." [17]

Slowly, a concept was forming that it is a moral duty of the international community to intervene and protect civilians from governments that cannot or will not do it themselves, implying that saving human lives could in some circumstances override sovereignty of the states. That is why humanitarian intervention at its core carries the UN principle of "The responsibility to protect $-R 2 P . "{ }^{\prime \prime}$ By 2005, the UN World Summit confirmed the final "Outcome Document” that legalized the possibility to conduct humanitarian intervention in cases of proven genocide, war crimes, ethnic cleansing or crimes against humanity.

Some politicians believe that to "Accept the doctrine of humanitarian intervention would mean the endangerment of the concept of independence and nonintervention in a world that reached no agreement on which moral postulates should actually guide humanitarian intervention." [18: 21] Any intervention, even the humanitarian one, contains in its nature forceful interaction in the affairs placed within the authority of another state. They claim that each state has a right to their own political independence, organization, traditional and cultural principles that can be different from American or West European, and that there are small chances for success of such operations when meddling into inner relations they know little or nothing about. Reasons against also include: questionable motives for intervention, resistance of different groups including the leading one in the area of intervention and also the simple fact that foreign actors cannot secure long term stability for any state unless there is motivation for change within. [19]

The positive side to this concept is that interference is focused on protection and well-being of the civilians. Supporters of the humanitarian intervention often emphasize the moral need to protect interests of all people, the right to fight for universal human good, for basic freedoms in each country and obligation to respect the interests and needs of civilians. If governments refuse or are incapable of doing this, then the foreign actors (international community) are forced to act.

Humanitarian intervention bases its legitimacy on the obligation to protect basic human rights, but it can only be validated if this action in not unilateral but authorized by a multilateral, internationally validated body and that action, as such, should be transparent, controlled and clearly focused on the main aim of the intervention.

\section{Case studies}

Crises most often arise when states lack popular legitimacy, either because they are wholly authoritarian (case of Libya in 2010), are under minority rule (case of Rwanda in 1994) or because they exclude ethnic minorities from full participation in a democratic political sys-

7 In 2001 Canada had set up an International Commission on Intervention and State Sovereignty, under the chairmanship of Gareth Evans, a former Australian foreign minister, and Mohamed Sahnoun, a former Algerian diplomat. In their report, published in 2001, it was they who first suggested changing the discretionary "right to intervene" into a more muscular "responsibility to protect". Available at http://www. economist.com/node/11376531 
tem (case of Mali in 2011). Similarly, Nathan says: "Put differently, the absence of justice is frequently the principal reason for the absence of peace.” [2] Oppressed and marginalized communities may seek to resolve the crisis through armed rebellion. Hostilities are likely to be intense and sustained because the stakes are so high.

Insurgents may prize freedom and justice more than peace. They may consequently be prepared to provoke and endure prolonged physical and political violence in order to achieve their goals. Quick peace settlements predominantly serve the interests of the ruling elite and its foreign sponsors, who wish to prove that they can maintain control over the country and that they possess the ability to suppress any violence or upheaval. In these circumstances, the cessation of hostilities is not in the interests of rebels as they need time to prove their strength, ability to challenge and disrupt ruling governance.

This article analyzes reasons and two different approaches of the international community to intra-state conflicts: support for the Afghan Government in its struggle against the Taliban insurgency, and on the opposite spectrum, support for Libyan insurgents in their fight against the regime of Muammar Gaddafi.

\section{Support for counterinsurgency: Case study Afghanistan}

To be able to fully understand the counterinsurgency strategy in Afghanistan, it is vital to be acquainted with the history of insurgency itself in this particular area. After the "Saur revolution" in 1978, a communist party named the "People’s Democratic Party of Afghanistan - PDPA" formed a new government with Nur Muhammad Taraki as the Head of the State. However, the deeply conservative and religious population did not respond favorably to the implementing of the socialist agenda by the PDPA, and by the spring of 1979 large parts of the country started an open rebellion against the government. After a year, it became clear that the government was not able to regain control and territorial integrity. Therefore, after he assassinated president Taraki, Deputy Prime Minister Hafizullah Amin requested Soviet military assistance. Although the USSR at first declined military intervention, it could not allow such an insecure environment at its border, and on Christmas Eve the Soviets launched the invasion, seizing key airfields and key government and communications sites in Kabul, occupying main cities and installing a puppet regime. ${ }^{8}$

The Soviets expected the resistance and war to end here but it was only the beginning. The Soviet army was not prepared for this kind of warfare as they were trained to wage wars on European plains, not in the mountains. They were forced to employ new techniques and strategies for fighting the Mujahedeen, the Afghan freedom fighters who came from a traditional warrior society and proved highly resourceful in fighting the Soviets. Although the Soviets were winning the battles, they were losing the war because the Mujahedeen were not willing to confront them on the open battlefield. They would simply come back and reestablish control over the area when the Soviet forces left. It was a stalemate where insurgents controlled the countryside and the Soviets controlled the cities.

Mujahedeen morale was higher, and with the help of foreign aid in weaponry, estimated to be worth \$66 billion from 1978-1992 [20: 238], they had significant efficiency. Another

8 New president was Babrak Kamal, former diplomat in exile, as the President. In the process they killed Hafizullah Amin, accusing him of being a brutal power-hungry leader who betrayed the Saur revolution and accusing him of being an American sympathizer or even a CIA agent. 
advantage was the support of Afghan Islamists by Pakistan, where the Mujahedeen could find new recruits and shelter. The new "Gorbachev foreign policy", ${ }^{9}$ along with the inability to control the Afghan countryside, was one of the many reasons for the Soviets' withdrawal. The plan was to prepare the Afghan army to fight without Soviet help and the withdrawal was finished by the beginning of 1989.

The Soviet withdrawal left Afghanistan in a collapsed state, which resulted in civil war. In 1992 major Afghan political parties agreed on power-sharing and establishing an interim government for a transitional period until the general elections. However, a significant group made of mostly ethnic Pashtu was regrouping in Kandahar. They were calling themselves the Taliban, which meant "students" or "seekers". They started to attract fresh recruits from religious seminaries with excessive funding by Pakistan's Inter-Services Intelligence in Federally Administered Tribal Areas in Pakistan - FATA and Waziristan, which was an effort to expand Pakistan's sphere of influence into Afghanistan with the help of the so-called proxy warriors. ${ }^{10}$ After a few years of sporadic fighting, the Taliban entered Kabul in 1996, and established the Islamic Emirate of Afghanistan. [21] By the end of 2000, the Taliban seized control of $90 \%$ of the country, imposing a strict interpretation of Sharia law. The only opposition, named Northern Alliance, was formed in the north of the country under the leadership of later assassinated Ahmad Shah Massoud. The assassination was conducted by the Al-Qaida operatives in return for allowing Afghanistan to become safe haven for shelter and training camps of Al-Qaida operations.

On $11^{\text {th }}$ September 2001, Al-Qaida members attacked the United States on their own territory killing more than 5,000 people. This was a turning point in NATO strategy toward insurgents and global terrorism, for the first time in history Article 5 of the North Atlantic Treaty was activated and Operation Enduring Freedom was launched. A wartime-like coalition was put together with over thirty countries which provided logistical, financial, diplomatic and political support. Military operations began on October 7, 2001 and within 75 days American coalition and anti-Taliban Afghan forces defeated and chased the Taliban, Al-Qaida and Pakistani insurgents into Pakistan. US officials claimed that "The Taliban is out of business, permanently"11 but they were deceived.

Again, the same scenario as with the Soviets happened. The coalition had achieved a military victory but an effective long term policy was not present. Taliban found sanctuaries in Pakistan and in the vast lands of their hometown, Kandahar, where they could retrain new recruits and prepare for a new phase of war. The Pakistani government could also wage another proxy war, this time against Coalition troops and president Karzai, who was in a way installed by the US. ${ }^{12}$ [22: 288] On the other side, Afghanistan Transitional Authority (ATA) was facing the task of rebuilding the country from ashes and almost no security forces at all to rely on.

9 Easing of Cold War tensions

10 proxy war $\mathrm{n}$. - a war instigated by a major power which does not itself become involved — Oxford dictionary

11 Taliban destroyed, says Cheney (18.11.2013) accessed at http://hindu.com/2002/03/14/ stories/2002031406201400.htm

12 Fight against the Taliban could not be waged in Pakistan. Exceptions are isolated and covert operations that target individuals, like the assassination of Osama bin Laden, which crippled the Al-Qaida leadership, but also in a way embarrassed the Pakistani Government, weakened the Coalition capacity for negotiation, which is an extremely important issue, simply because Pakistan still sees the Taliban as a valuable asset in bringing Afghanistan into its sphere of influence, and the US-led Coalition's primary goal in this matter should be to cut all links between the Taliban and Pakistani army. Estimates are that between 1994 and 1999, 80,000 to 100,000 Pakistanis trained and fought in Afghanistan. [22] 
To assist them with this challenge and assure that the Taliban regime did not return to power, the international community stepped in, and at the beginning of 2002, in accordance with UN Security Council Resolution 1386 established the International Security Assistant Force - ISAF. While troops assigned to operation "Enduring Freedom” were still fighting the pockets of Taliban resistance, ISAF's main role was securing Kabul and the surrounding areas, acting as military support for the Government and the creation of Afghan National Security Forces.

By 2006, it became obvious that the NATO strategy for securing and stabilizing Afghanistan was not working. As the attacks on NATO and Afghan Security Forces (AFS) troops drastically increased, it became obvious that the Taliban were not defeated, they had regrouped, rearmed and were ready to fight for power and territory once again. ${ }^{13}$ This time they were backed up by allies from Hezb-i-Islami, the Haqqani network, foreign fighters from Pakistan, local tribes that had rejected the Karzai rule and criminal organizations involved in opium production and trade. Counterinsurgency operations had to be initiated.

As the local Security Forces and Government were still too weak, US forces assumed the leading role in COIN.

The first COIN strategy was not as effective as the international community hoped it to be. One of the main reasons was that the majority of the Afghan population live in the countryside, where central governance from Kabul has a weak and almost invisible reach. The occasional flood of foreign soldiers, concentrated in small Provincial Reconstruction Teams (PRTs), into neighboring villages, just to pull back behind walls hours or days later, triggered additional dissatisfaction, frustration and unrest among the population. Any aid or help brought to them in attempts to "win hearts and minds" just triggered the insurgents' rage, and they would reappear as soon as foreign troops left. These troops and efforts were seen as occupying, exploiting and hostile. Thus, the number of Alliance casualties constantly increased and by 2009 doubled in numbers. COIN strategy had to be changed.

Based on the analysis of 90 insurgencies since 1945, Seth Jones wrote in his study "Counterinsurgency in Afghanistan" that there are "three variables correlated with the success (and failure) of counterinsurgency efforts: capability of indigenous security forces (especially police), local governance and external support for insurgents including sanctuary.” [23] This and the arrival of former US Special Forces General Stanley A. McChrystal and Iraq Veteran General David H. Petraeus, as consecutive ISAF commanders, changed the operational design and dynamics of the second Afghanistan COIN. Foreign military troops pulled back and local Security Forces and Government officials pushed front, still backed and supported by ISAF.

Their plan was to activate COIN in two separate directions. The first, "populationcentric" strategy emphasized the need to satisfy economic, social and political grievances through three COIN "lines of operations" — security project, governance, and development. Security and governance could be improved by short-term projects, even without any longterm policy. The idea assumes that development aid will promote local stability and win political support.

The second strategy was to continue training and equipping ASF, but now through a concept called “embedded partnership". In its core was the idea to rapidly bring ASF to a phase where they would conduct their tasks, missions and operations independently, but according

13 http://icasualties.org/oef/ accessed on 15 November 2013 
to western standards. This was to be done by embedding NATO troops into Afghan Security Forces. They were not just training together, but also living, sleeping, eating and fighting together. Slowly, NATO troops pulled out leaving COIN with a fully “Afghan face” and full local ownership.

However, 4 years into second COIN, billions of dollars invested in the country have done little to increase the population's support for the Afghan Government or support against the Taliban, and the fact is that the most stable areas are the ones that have not received any aid or received a small share of it. The main reason is the flourishing corruption in the Afghan Government in certain areas, combined with opium production and involvement in local power struggles, which is a sign of inefficient Government apparatus.

On the military end, two problems occurred: The ASF troops started acting and fighting as the NATO troops, they were no longer deemed local, but seen as an extended hand of the "occupying force”. Constant home searches were viewed as attacks on family honor, and some incidents by Coalition soldiers have damaged the relations between the domicile population and Coalition forces and/or Afghan officials. Another gap opened as the exit strategy of Coalition forces was developed. After the 2014 transition, Afghan military and police, although well trained and impressively equipped may have problems effectively fighting the Taliban, and even more sustaining and maintaining the complex bases, facilities and equipment they were given. In these circumstances, the withdrawal of Western forces could lead to a collapse of the entire security sector.

As an answer to that, president Karzai attempted reconciliation with the Taliban, and negotiations are still in progress. The Taliban are not fighting to be accommodated but to bring the State down or at least gain their own autonomy in the south and east of the country. [24] The coalition has started its military withdrawal, but without any doubt, for the past 11 years it has actively supported and backed the Afghan Government in its fight against insurgency.

\section{Support for insurgency: Case study Libya}

When, on 15 February 2011, Muammar Gaddafi's security forces opened fire on protesters inspired by uprisings in Tunisia and Egypt, a seed, which would eventually end Colonel's forty year long career as an autocrat in Libya, was planted. Protests began in the eastern city of Benghazi, controlled by the Gaddafi opposition and some defected military units, and slowly spread across the country. In the area where the fighting was intense, reports claimed that the Government was using firearms and even heavy artillery and cluster bombs against protesters in civilian areas. The international community condemned that kind of action and responded accordingly.

The first international measure came on 26 February 2011, when the UN Security Council adopted resolution no. 1970 that imposed an arms embargo, travel ban for members of the Gaddafi regime and an asset freeze. It also referred the actions of the Government to the International Criminal Court (ICC) for investigation. However, Gaddafi ignored the measures and launched a counterattack pushing the rebels back and approached Benghazi and Misrata, which, on $17^{\text {th }}$ March 2011, triggered the second UN resolution no. 1973 imposing a no-fly zone over Libya and authorizing "to take all necessary measures... to protect civilians and civilian populated areas under threat of attack in the Libyan Arab Jamahiriya, including Benghazi, while excluding a foreign occupation force of any form on any part of Libyan 
territory." [25] Immediately, the Libyan Government announced a ceasefire, but nevertheless continued with the shelling of rebel-controlled cities and regime soldiers continued approaching Benghazi.

Because of that, some of the European members of NATO, backed by partner countries of the Arab League, ${ }^{14}$ decided to launch operations in support of UN SC resolutions. The United Kingdom initiated operation "Ellamy”, France operation "Harmattan” and the US launched the military operation "Odyssey Dawn”. At the same time, NATO was preparing for its mission, and on $23^{\text {rd }}$ March 2011, operation "Unified Protector” absorbed all other international operations in Libya. After the command transfer, three tasks were initiated:

Policing the arms embargo. Even before the uprisings, Gaddafi feared a military coup so he kept regular military units poorly armed, with just four brigades of highly equipped and trained soldiers. Therefore, NATO ships performed a maritime blockade with the mission to monitor, report and interdict vessels suspected of carrying arms or mercenaries, however, NATO ships did not enter Libyan territorial waters.

Patrolling the no fly-zone. It was successfully conducted after initial strikes had destroyed all Government air defense capabilities. The few Ally losses were mainly due to mechanical malfunctions.

Protecting the civilians. The only way to protect civilians was through air strikes on Gaddafi's ground forces, but the problem was the proximity of the regime's forces and other assets to civilian infrastructures with reported use of human shields by forces loyal to the regime. ${ }^{15}$ Similarly, insurgents also used civilians for refuge, resupply and shield.

By August 2011 rebels rallied under the National Transitional Council of Libya (NTC) became internationally recognized as the legitimate governing authority in Libya. The ICC issued an arrest warrant for Gaddafi and his closest associates for war crimes and crimes against humanity. After a certain stalemate, with the help of NATO-led aerial intervention, opposition launched attacks on Tripoli and Gaddafi's hometown Sirt, and eventually overpowered forces loyal to the regime and captured these cities. Two months later, NTC secured control over the whole of Libya and Operation Unified Protector ended on October 31, 222 days after it had begun.

It can be concluded that NATO's involvement in the conflict was in fact in support of the rebels as it played a crucial role in the rebels' campaign to overthrow the regime. ${ }^{16}$ The fact that the rebels were recognized as the legitimate representative of Libya and the fact the NATO bombed Gaddafi's residence only corroborated that NATO and the West would settle for a regime change. Because of that, some claim NATO went beyond its limits, as provision of military assets to the rebels was not part of adopted UN resolutions. Nevertheless, NATO stayed within the limits of the mandate, as the mission was solely airborne and many civilian lives were saved. ${ }^{17}$

14 Qatar, Jordan, Morocco and UAE

15 Mission aborted on orders of SAS: RAF attack is halted after troops spot human shields (20 11 2013) from http://www.dailymail.co.uk/news/article-1368626/Libya-RAF-abort-attack-SAS-spot-Gaddafi-using-humanshields.html

16 NATO has "played a decisive role” in Libya (20 11 2013) from http://www.dw.de/nato-has-played-a-decisiverole-in-libya/a-15346089-1

17 French Air Force itself launched over 4,500 flying missions and hit around 2500 military targets. The French airmen continue their mission in Tripoli (20 11 2013) from http://www.lepoint.fr/editos-du-point/jean-guisnel/ les-aviateurs-francais-poursuivent-leurs-missions-sur-tripoli-22-08-2011-1365090_53.php 


\section{Conclusion}

Internal conflicts, whether instigated by the government or the insurgents, generate tension and mistrust between states and in the region, in ways that prevent them from attaining mutual confidence, stability and security needed to create and maintain a healthy, functioning and prospering community. Cross-border violence, hostilities, rebel attacks from neighboring countries, military action by governments against rebel movements, or collective enforcement action intended to restore domestic order are just some of the consequences of uncontained conflicts.

Weak and fragile states are incapable of restraining instabilities and crisis within, thus forcing the international community to "step in" and take charge in separating opposing sides, negotiating peace settlements and reestablishing a stable environment. Whether this is done with or without support of the ruling elites is far less important than the international security, safety of the local population and regional political and economic stability.

\section{References}

[1] UN: Charter of the United Nations. San Francisco: UN, 1945. http://www.un.org/en/ documents/charter/chapter1.shtml (accessed: 1511 2013)

[2] NATHAN, L.: The Four Horsemen of the Apocalypse - The structural cause of violence in Africa, Track Two. 102 (2001), 1-13. DOI: https://doi.org/10.1016/S0958-2118(01)80109-9

[3] WHAITES, A.: States in Development: Understanding State building. UK: Department for International Development, Policy and Research Division, 2008.

[4] HOBBS, T.: The Levijatan. Zagreb: Naklada Jesenski i Turk, 2004.

[5] McIOUGHLIN, C.: Topic guide on Fragile States. Birmingham: GSD RC, 2010.

[6] NATHAN, L.: Security Communities and the problem of Domestic Instability. Working paper no. 55, London: Crisis States Programme Development Research Centre, 2004.

[7] NATO Allied Joint Doctrine for Counterinsurgency (COIN). AJP 3.4.4. February 2011.

[8] Field Manual Interim: Tactics in Counterinsurgency. FM 3-24.2, Washington, DC: Headquarters Department of the Army, 2009.

[9] BRYMAN, D., CHALK, P., HOFFMAN, B., ROSENAU, W., BRANNEN, D.: Assessing the Impact of External Support, from Trends in Outside Support for Insurgent Movements. (Chapter 6) Santa Monica: RAND, 2001.

[10] PAUL, C.: Counterinsurgency Scorecard - Afghanistan in 2011 relevant to the insurgencies of past 30 Years. Santa Monica: RAND, 2011.

[11] NATHAN, L.: Security Communities and the problem of Domestic Instability. London: Crisis States Research Centre, LSE (Working paper no. 55) 2004. (available: http://eprints. lse.ac.uk/28204/1/wp55.pdf)

[12] US National Defense Strategy. Washington DC, 2008.

[13] POOLE, J.: Terrorist Trail - Backtracking the foreign Fighter. Emerald Isle: Posterirty Oress, 2009.

[14] HEYMAN, C. (Ed.): Jane’s World Armies. London: Jane’s Information Group Limited, 2002.

[15] WADE, M. N.: The Operations Smart Book. Third Revised Edition, USA: The Lightning Press, 2002.

[16] Special operations doctrine. JP 3-05, Tampa: USSOC, 2011.

[17] PBS Newshour: The Blair Doctrine. 2204 1999, (available: http://www.pbs.org/newshour/ bb/international/jan-june99/blair_doctrine4-23.html)

[18] GRIZOLD, A., ČEHULIĆ, L.: Međunarodna sigurnost i NATO u novom svjetskom poretku. Zagreb: Fakultet političkih znanosti, 2006. 
Vlasta ZEKULIĆ, Ana ŽUŽIĆ, Adam PIŠKULIĆ: Support to insurgency and counter insurgency operations

[19] HILLEN, J.: The blue helmets - The strategy of UN Military Operations. Dulles: Brassey's Inc., 2001.

[20] COLL, S.: Ghost wars, the Secret History of the CIA, Afghanistan and bin Laden. London: The Penguin Press, 2004.

[21] MANZAR, S., ZAIDI, A.: The New Taliban Warlords and Organization. Defense Against Terrorism Review, 12 (2008) 67-88.

[22] MALEY, W.: The Afghanistan wars. New York: Palgrave Macmillan, 2009.

[23] JONES, S.: Counterinsurgency in Afghanistan. Santa Monica: RAND, 2008.

[24] ABDULLAH, A.: Talks with Taliban Futile. (18 11 2013) (available: http://www.npr.org/ templates/story/story.php?storyId=130757482)

[25] UN Security Cuncil Resolution 1973. (available: http://daccess-ods.un.org/ TMP/64320.7132816315.html) 